\title{
The Numbers Line Media to Improve the Ability of the Students In Calculating Integer Operation
}

\author{
Muhammad Sholahuddin Arif ${ }^{* *}$, Kholifah Kholifah ${ }^{2}$ \\ ${ }^{12}$ Fakultas Keguruan dan Ilmu Pendidikan, Universitas Ronggolawe \\ $\risingdotseq$ e-mail: msholahuddinarif23@gmail.com
}

\begin{abstract}
The interested thing to study on the teaching and learning strategies in elementary school is the understanding of the development of the learners at once the uniqueness that is required the teachers on identifying suitable actions (behavior in children) as a goal that can be achieved in the teaching, the activities and the learning experiences for certain age groups, and the evaluation system to be used. Therefore, this reason become strong in order to the teaching system that was developed by the teacher is expected to be increasingly able to serve the requirements of the individual learner (individually guided education) and the teaching become interested and meaningful for children. Moreover, the purpose of this study is used to improve the learning outcomes of the mathematics subject which calculate the Additional Operation and Integer Reduction material, especially at remote rural schools. In addition, the purpose is to determine the extent of the effectiveness of the use of numbers board media to improve the mathematics achievement which calculates the Additional Operation and Integer Reduction material in class IV SDN Bektiharjo VI Kecamatan Semanding. The data that used were obtained from the test results and observations of the students in the process of the teaching and learning by the number of 24 children. The result of this study that was obtained by the observation from the teacher to the students on the learning process has increased in each cycle. In the first cycle of the observation has the total score is 52 and it has increased on the second cycle which has the total score is 69. Furthermore, the result of the students' mathematic subject which the school standard value of SDN Genaharjo VI is 70 was also increased from the first cycle of the total value in 1650 with an average of 68.7 and the second cycle of the total value in 2030 with an average of 84.5 .
\end{abstract}

Keyword: mathematics, numbers board media, additional operation and integer reduction

Copyright (C) 2018 IICET (Indonesia) - All Rights Reserved

Indonesian Institute for Counseling, Education and Therapy (IICET)

\section{INTRODUCTION}

One of the main tasks of the teacher to actualize the aims of the education in the school is develop the teaching and learning strategies effectively (Armour, K. M., \& Yelling, M. 2007; Schmeck, R. R. (Ed.). 2013; Stronge, J. H. 2007). This teaching and learning strategy development is to create the conditions which can affect the learners so they can learn fun and get satisfactory academic achievement (Kuh, G. D., Kinzie, J., Schuh, J. H., \& Whitt, E. J. 2011; Entwistle, N. J. 2013). Doing the teaching and learning effectively is a complex work and demand a seriousness of the teacher.

The comprehension of the learners' development and their uniqueness will be required by the teacher to identifying suitable actions (Crowther, F., Ferguson, M., \& Hann, L. 2009; Ramírez, V. A. C. 2010) (behavior 
in children) as a goal that can be achieved in the teaching, the activities and the learning experiences for certain age groups, and the evaluation system to be used. An understanding of the individual dimension that recognizes the diversity of family backgrounds of the learners, make a teacher will consider that the importance of the parents' active involvement either as a source or as a decision maker at once about treatment accuracy or individual services for children's education.

Having regarded to the terms of individuality, characteristics of primary school, and the various dimensions of their development, then a teacher not to develop the teaching as her pleases in the class. In developing on her teaching system, a teacher not deviates from the principles of existing psychological. Therefore, this reason become strong in order to the teaching system that was developed by the teacher is expected to be increasingly able to serve the requirements of the individual learner (individually guided education) and the teaching become interested and meaningful for children.

Connection with the implementation of the tasks above, develop the teaching and learning strategies effectively, a teacher requires the considerable base knowledge about the teaching and learning strategies approach which oriented to the development of the learners.

Furthermore, the teaching and learning activities for primary school have its own meaning and purpose. It is closely linked to the characteristics of the children their self. An elementary school teacher should be understood that the component of the child is the most important thing in teaching process. Therefore, the teaching process must be created on the basis of understanding who and how children grow and develop. In other words, the teaching and learning activities which practically developed by the teacher in primary school is required to be oriented on the development of children appropriately.

In the mathematics subject especially in the Additional Operation and Integer Reduction as noted in the 1994 curriculum or curriculum in 2006 were introduced in primary students in grade IV (four) basically not all of the learners are able to calculate the additional operation and integer reduction properly, especially in remote rural school. It is caused by the characteristics of the environment and communities in rural areas that support the purpose of education itself. Moreover, the learning models and the teaching, the learning strategies are implemented and used by the teacher are less understood by the students, so that they are very slow at accepting learning materials mainly in the additional operation and integer reduction. It seems to occur in the fourth grade SDN Bektiharjo VI Kecamatan Semanding Kabupaten Tuban.

That is why, to solve this problem, a teacher is demanded to do variety of ways by using a variety of the teaching and learning strategies which appropriate to the characteristics of the children. One of that ways is using number board media which can improve the ability of the additional operation and integer reduction to the children. By using the number line media is expected to improve the learners' additional operation and integer reduction ability. At the same time, by using this media the achievement in mathematics will increase as well.

\section{THEORICAL REVIEW}

The data was taken to the learners grade IV SDN Bektiharjo VI Semanding Tuban by directly observation. The object of the observation is the observation process of the learning to observe the teacher's readiness on the teaching and learning process (Borich, G. D. 2016; Chong, W. H., \& Kong, C. A. 2012). The function of the observation is documenting related effect with the process, and then it tested as an indicator of the student success (Madya, 2006). Arikunto (2002) stated that the test is the number of questions or exercises used to measure the skills, the knowledge, the intelligence, the abilities, and the talents of the individual or group. The test aims to measure the students in terms of the cognitive aspects by giving the final test on the teaching and learning process (Larsen, D. P., Butler, A. C., \& Roediger III, H. L. 2008; Michel, N., Cater, J. J., \& Varela, O. 2009). The test is in the form of the observation sheets that required the teacher in a reflection activity as the follow up results about the success of the learning object in each cycle. On the teaching and learning process, there is a data collection criteria of the teacher's grade, (1) Bad = 18 - 31, (2) Poor = 31 44, (3) Good Enough = $44-57$, and (4) Good = $57-70$. Moreover, in mathematic lesson has standard grade 70. If the grade is on the standard then the student has been completed in this subject, otherwise if it is under the standard then they need more assistance. 


\section{The Mathematic Learning in Elementary School}

The understanding of mathematics in elementary school according to Arifin (2009) stated that "phrase which used to formulate the understanding of mathematics is really to present the whole field and the object of study which has developed, being developed or will be developed in mathematics. Not a few of a mathematician who succeeded to formulate the understanding of mathematic. The reason is the teaching activities are not simply linked to the issue of conveying messages from the teacher to the learners. This is actually about how the teacher guides and trains the learners to study, so that the professionalism of the teacher is required.

To facilitate the teaching and learning process, the teacher must comprehend and master the characteristics of learners. Morgan et al (1986) stated the meaning of modern learning as every changes of behavior which is consistent and occurred as a result of training and experience. This definition contains two important elements in the learning. First, the learning is a behavior change; second, the change that occurred because of the training or the experience. Meanwhile, Davis (1971) stated that the learning as a professional activity that requires a high skills and covers decision-making.

In short, the teaching and learning strategies basically cover four main points, (1) the teaching goal setting, (2) the teaching and learning approach system election, (3) the election and procedure determination, the methods, the teaching and learning techniques, (4) the success criteria of establishment the teaching and learning process from the evaluation (Twelker, 1972). The teaching and learning strategies in mathematic is closely related to the student interest in the learning to understand the material. So, the atmosphere of mathematic learning will become fun (joyful learning).

The mathematic material was studied by the children that interested them has been limited in the scope of the core study materials based on The Teaching Program of The Government Rules (ITB's Team, 2002). First, the introduction of a concept supposed to do by using a problem. Second, the problems are presented as far as possible in the form of the problem that has meaning. Third, the additional operation and integer reduction are an integral part of every aspect of learning material. The ability of comprehend the material must involve the ability to solve the additional operation and integer reduction. Fourth, in delivering the example of a concept supposed to variety of comprehensive examples sufficiently. Thus, the learners do not make a narrow perception about the concept. Fifth, there are some phases to introduce the concept, the concrete phase, then the semi concrete, and the last is the abstract phase.

\section{The Line Numbers Media}

One of the mathematic learning media for primary school is by using the line numbers media. The line numbers media is a prop that utilize the cardboard/ wooden board or make the squares on the floor like boards which the each surface is written an integer form to count the additional operation and the integer reduction on the teaching and learning process of mathematic study. It is to simplify the learners to comprehend the subject on mathematic study.

$$
\begin{array}{|l|l||l||l||l|l||l|l||l||l|l||l||l||}
\hline-6 & -5 & -4 & -3 & -2 & -1 & 0 & 1 & 2 & 3 & 4 & 5 & 6 \\
\hline
\end{array}
$$

Figure 1. The example of The Line Numbers Media

Generally, we have known that the children will be bored easily on discourse method of the teaching and learning process. Then, they felt difficult to retrieve and comprehend the material. For the children who have high intelligence certainly have no obstacles to do it, otherwise who have low intelligence or have slow way of intellective will comprehend hard of the material that has delivered.

Tabel 1. The rules of the line numbers media

\begin{tabular}{cc} 
The Operation & Direction \\
Additional Operation & Go Forward / Stay \\
Reduction Operation & Turn Right \\
\hline
\end{tabular}




\section{Positive Integer $\quad$ Step Forward \\ Negative Integer $\quad$ Step Back}

The Examples of how to apply the number line media in calculate the additional operation and the integer reduction are : $3+(-2)=\ldots$.

Based on the example, there are two integers and one operational, the positive integer (3) and the negative integer $(-2)$. Now, the additional operation and the way of operation are:

\section{The Starting Position to the Zero Turns to The Right}

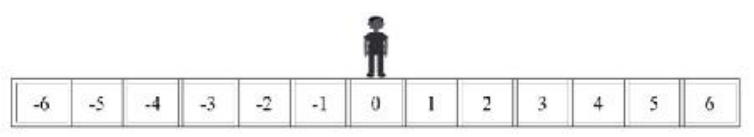

Figure 2. The starting position

Because of the operation is + (plus) so, fixed position.

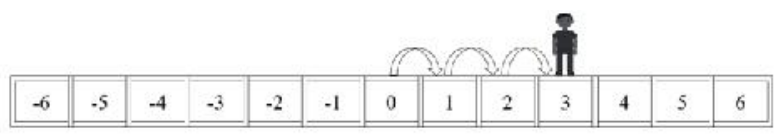

Figure 3. The operation is + (plus) three

Because of the operation is (-2) that negative integer so two step back

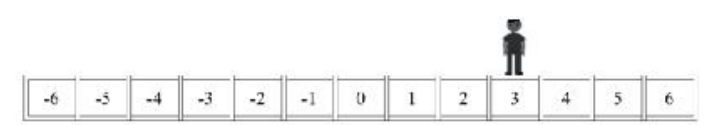

Figure 4. the operation is (-2) that negative integer so two step back

Thus, $3+(-2)=1$

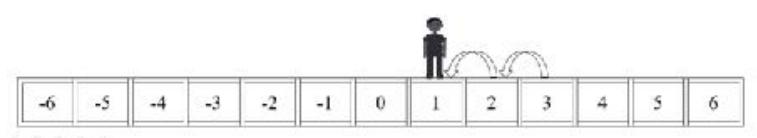

Figure 5. The ending position

\section{METHOD}

According to Kemmis and Mc Taggart (1985), the procedure to implement a class action research consists of, (1) the Plan, (2) the Implementation Research, (3) the Observation, and (4) the Reflection. The researcher acts as the teacher, meanwhile the lesson teacher acts as the observer with another observer who assigned to observe the teaching and learning process. Before the observation, the observer should acquire the result of the teaching and learning process before using the line numbers media to calculate the additional operation and integer reduction which called pre Cycle. Next, implement the cycle I and cycle II that include the action plan, the implementation of the action, the observation, and the reflection.

The cycle I consists of: first, specify the competency standard, the basic competency, and the indicator of the learning objective; second, arrange the learning objective; third, arrange the implementation of the learning; fourth, prepare the number board media; fifth, prepare the topic to be studied; sixth, prepare the research instruments such as the observation sheet and the student worksheet that used to find out the implementation and the achievement of the learners. Furthermore, in the cycle I the researcher identifies the problem by arranging the learning media, such as:

1. Define the purpose of the mathematic subject towards the additional operation and integer reduction.

2. Specify the teaching strategy by the number line media. 
3. Arrange the observation instrument of the learning activities, the assessment guidance of the learning outcome, and the reflection.

Moreover, the cycle II that can be as the improved learning toward cycle I if there is the deficiency, the researcher applies the similar way with cycle I to arrange the learning media. The difference is cycle II uses the Live Action method to individual or each student so they comprehend to calculate the additional operation and integer reduction easily by using the numbers board media.

\section{RESULT AND DISCUSSION}

Based on the experience and the observation in the class, especially in the grade IV SDN Bektiharjo VI Tuban, find that the students difficult to calculate the additional operation and integer reduction. They do not know or disable how to calculate easier and fun thus the mathematic subject as a nightmare and frightened thing. The pre cycle data about the additional operation and the integer reduction of mathematic subject that observed before using the number line media in the grade IV SDN Bektiharjo is the average value still under the standard of 70. Based on the total of the student's score in the pre cycle formative test is 1430 at the average value 59,5. It can be concluded that the teaching and learning activities before cycle obtain a poor result which has the average value under the standard. Thus, the improvement activities are required on the cycle.

The first activity in the cycle I that calculates the additional operation and the integer reduction of mathematic subject is by using the number line media. First, prepare the number line media and the students start to answer the questions by using this board media in front of the class alternately. Based on this activity it has the data result that could be analyzed and treated. If the learning results achievement in cycle I has improved, the cycle II is not required to do. Otherwise, if there is a deficient outcome, the cycle II is required to improvement. The teaching and learning activity for cycle I was held on Wednesday, April $24^{\text {th }} 2013$ in second semester at period 2012/2013 to 24 students grade IV SDN Bektiharjo VI Tuban. At this stage, the teaching and learning activity was held based on the improved plan that has arranged.

In the first cycle, the amount of value is 52 which included category 3 (good enough) and the average value is 2,8 . In conclusion, the activity of the teacher and the students has balanced as well as the improved plan learning on cycle I. The teaching and learning activity in the first cycle has been increased; however it is still lack since the average value was under the standard 68,7 by the total value is 1650 . In other words, this result has not been thorough until the improvement on the next cycle. Based on the observation of the cycle I which is required to implement the improvement in the next cycle, the researcher has dialogue with the teacher to solve the problem. The Live Action Method both individual and each student were found from the discussion in order to the students comprehends to calculate and apply the additional operation and integer reduction easier by using number board media.

The second cycle of the teaching and learning activity was held on Wednesday, April $28^{\text {th }} 2013$ in second semester at period 2012/2013 to 24 students. At this stage, the teaching and learning activity was held based on the improved plan that has arranged as usually. In this cycle, the amount of value is 69 which included category 4 (good) and it is better than previous cycle that have the average value is 3,8 . Thus, the teaching and learning activity between the teacher and the students is balance. This is appropriate with the improved plan of the learning on cycle 2 . The observation outcome shows that the total of the students in the improvement test of the cycle II is 2030 with the average value is 84,5. In conclusion, the teaching and learning activity on second cycle has obtained satisfy result, therefore the average value is above of the standard value or complete learning and the improvement is not required to do in the next cycle.

\section{The Using Number Line Media on the Teaching and Learning Activity}

Based on the observation result, the teaching and learning activity between the teacher and the students on calculates the additional operation and the integer reduction of mathematic subject by using the number line media has increased. The teacher was very helpful in explaining, informing and providing the comprehension of the students to calculate on the mathematic subject. The students are also more active, guided, and motivated to comprehend the subject without feel the mathematic subject is a nightmare anymore. This was proved by the activities table of the teacher on the teaching and learning process. The total amount the average value in the each cycle of both the teacher and the students were increased. The total value of the 
first cycle is 52 with the average value is 2,8 meanwhile in the second cycle is 69 with the average value is 3,8 .

\section{CONCLUSION}

From the data analysis by using the individual Live Action Method was found that the improvement of the learning results. Thus, it could be concluded that the using Integer Line Media helps the students to increase the ability of calculate the additional operation and the integer reduction on mathematic subject. It was proved by the students of grade IV SDN Bektiharjo VI Tuban at period 2012/2013. The analysis discussion showed that the average value of the test result has increased in pre cycle with the average value is $\mathbf{5 9 , 5}$, on the cycle $\mathbf{1}$ is $\mathbf{6 8 , 7}$ and the cyle II is $\mathbf{8 4 , 5}$. Based on the pre cycle, cycle I, and cycle II showed that the effectiveness of the learning to calculate the additional operation and the integer reduction on mathematic subject produces the following data are 68,7 (Cyle I) - 59,5 (Pre Cycle) $=9.2$ and 84,5 (Cycle II) - 68,7 $($ Cycle I $)=15,8$. Therefore, calculating the additional operation and the integer reduction by using the number line media from the cycle I and cycle II is increase.

\section{REFERENCES}

Arifin, Zainal. (2009). Metode Penelitian Pendidikan. Surabaya: Lentera Cedikia.

Arikunto, Suharsini. (2001). Dasar-Dasar Evaluasi Pendidikan. Jakarta: Bumi Aksara.

Armour, K. M., \& Yelling, M. (2007). Effective professional development for physical education teachers: The role of informal, collaborative learning. Journal of teaching in physical education, 26(2), 177-200.

Borich, G. D. (2016). Observation skills for effective teaching: research-based practice. Routledge.

Chong, W. H., \& Kong, C. A. (2012). Teacher collaborative learning and teacher self-efficacy: The case of lesson study. The Journal of Experimental Education, 80(3), 263-283.

Crowther, F., Ferguson, M., \& Hann, L. (2009). Developing teacher leaders: How teacher leadership enhances school success. Corwin Press.

Davis, IK. (1971). The Management of Learning. London: McGraw-Hill Book Company.

Entwistle, N. J. (2013). Styles of learning and teaching: An integrated outline of educational psychology for students, teachers and lecturers. Routledge.

Gravemenijer, K. (1999). Educational Development and Development Research in Mathematics Education. In Journal For Research in Mathematics Education, 25 (5), 443-471.

Hopskins, David. (1993). A Teacher Guide to Classroom Research Second Edision. Philadelphia: Open University Press.

Kuh, G. D., Kinzie, J., Schuh, J. H., \& Whitt, E. J. (2011). Student success in college: Creating conditions that matter. John Wiley \& Sons.

Larsen, D. P., Butler, A. C., \& Roediger III, H. L. (2008). Test-enhanced learning in medical education. Medical education, 42(10), 959-966.

Madya, Suwarsih. (2006). Penelitian Tindakan: Action Research. Bandung: Alfabeta.

Michel, N., Cater, J. J., \& Varela, O. (2009). Active versus passive teaching styles: An empirical study of student learning outcomes. Human Resource Development Quarterly, 20(4), 397-418.

Morgan, C.T. and King, R.A. (1986). Introduction to Psychology. New York: McGraw-Hill Book Company.

Ramírez, V. A. C. (2010). Students' perceptions about the development of their oral skills in an English as a foreign language teacher training program. Unpublished Ph. D thesis. Universidad Tecnológica De Pereira, Columbia.

Schmeck, R. R. (Ed.). (2013). Learning strategies and learning styles. Springer Science \& Business Media.

Stronge, J. H. (2007). Qualities of effective teachers. ASCD.

Tim ITB. (2002). Pengkajian Kurikulum dan Model Pembelajaran Mata Pelajaran Matematika. Rangkuman hasil penelitian yang diseminarkan dalam Seminar Nasional Direktorat TK dan SD dirjen dikdasmen Depdiknas di Jakarta.

Twelker, P. A. Urbach, Floyd d \& Buck,J.E. (1972). The Systematic Development of Instruction. Stanford: ERIC Clearinghouse on Media and Technology.

Wijaya, A. Cece. (1991). Kemampuan Dasar Guru dalam Proses Belajar Mengajar. Bandung: PT. Remaja Rosada Karya. 